\title{
EDITORIAL
}

\section{In This Issue: Clinical Diagnosis and Management}

\author{
Kurt C. Stange, $M D, P b D$, Editor \\ Ann Fam Med 2007;5:290-291. DOI: 10.1370/afm.732
}

$\mathrm{T}$

his issue provides insights into clinical diagnosis $^{1}$ and management ${ }^{2,3}$ of patients with conditions commonly seen in primary care. A cohort study $^{4}$ and 2 clinical trials ${ }^{5,6}$ offer new ways of managing or preventing common conditions.

In a cohort study of 1,871 patients, preventive labor induction is associated with a lower rate of cesarean delivery. ${ }^{4}$ Editorials by Caughey ${ }^{7}$ and Klein ${ }^{8}$ present contrasting perspectives and considerable context for interpreting this study and for considering the application of its provocative findings in practice.

In this time of controversy surrounding the widespread administration of human papillomavirus (HPV) vaccination $^{9-15}$ an ethnographic study by Sussman et a ${ }^{16}$ provides useful insights into how primary care clinicians think about providing anticipatory guidance about sexual health risks and HPV vaccination during office visits by adolescent patients. This study was conducted shortly before the HPV vaccine became available in the United States.

Herpes zoster infection commonly is diagnosed by clinical judgment. A study by Opstelten and colleagues ${ }^{1}$ finds that family physicians' clinical judgment and a rapid dried blood spot test both have high degrees of accuracy compared with serologic confirmation of infection.

In a randomized clinical trial among the challenging group of patients with medically unexplained physical symptoms, Escobar and colleagues find that a cognitive behavior therapy intervention reduces patients' symptoms at treatment completion. These effects persist but diminish with time. ${ }^{6}$

In another clinical trial, Dietrich and colleagues evaluate a streamlined prevention care management intervention. ${ }^{5}$ They find that it improves screening rates for colorectal cancer, but not cervical and breast cancer. Delivery through a Medicaid managed care organization shows the feasibility of providing central telephone support for patients seen in diverse primary care practices.

\section{HEALTH CARE SERVICES DELIVERY}

Referrals are common in primary care, but how often patients actually go to the referred physician is not known. Forrest et al study a cohort of 776 patients referred from 133 physicians in 81 practices in 30 states. ${ }^{3}$ They find that about $80 \%$ of patients actually complete the specialty referral within 3 months. Factors associated with completion have implications for practice and health care system organization.

Both religious traditions and the practice of medicine at times use a sense of "calling" as motivation for caring for the underserved. A study by Curlin and colleagues finds that specific aspects of physicians' report of personal spirituality and background, but not general measures of religiosity, are associated with reported care of the underserved. ${ }^{17}$

A study of 112 Spanish primary care physicians asks how frequently clinical questions occur and are answered during outpatient visits. ${ }^{2}$ In 3,511 videotaped consecutive visits that averaged 8 minutes, they find that physicians searched for answers to $23 \%$ of the questions. Only $10 \%$ of questions were answered during the patient visit. As does previous similar research in the United States, ${ }^{18-22}$ this work shows the need for efficient and effective ways of answering clinical questions in real time. ${ }^{23}$

A Canadian study is relevant for initiatives to reform primary health care. Haggerty et al use a Delphi process to define care characteristics proposed for current or reformed primary health care. ${ }^{24}$ They develop operational definitions for 25 attributes, only 5 of which are rated as specific to primary care.

We encourage readers to participate in the Annals Journal Club ${ }^{16,25}$ and to share your insights by joining the Annals online discussion at http://www.AnnFamMed.org.

\section{IMPACT}

An essay and accompanying oral history by John Frey trace the origins of family medicine through the life of one of its founders-John Geyman, MD. ${ }^{26}$ We recom- 
mend this essay to readers who are familiar with Dr Geyman's large impact on family medicine, and particularly to readers who may be less familiar with his seminal role in the development of the discipline and his more recent efforts to promote health care reform.

After 4 years of publication and 3 years of being indexed, the Annals has received its first impact factor in the 2006 Journal Citation Reports. The journal impact factor is the ratio of the number of citations in the current year to a journal's articles published in the previous 2 years, divided by the number of a journal's "substantive articles and reviews published in the same 2 years." 27,28 The Annals inaugural impact factor of 3.8 places it in the top 15 in the large category of general medical journals. ${ }^{29}$ This is gratifying, and we are appreciative of the many people who are making the Annals a forum for sharing new knowledge about primary care, health care, and health.

Nevertheless, the impact factor is an imperfect and controversial measure of a journal's influence, ${ }^{30-34}$ and citations in the scientific literature are only one component of impact. We ask authors to provide us with their best work, and readers and online commenters to consider together the implications of this work for practice, policy, research, education, and other uses. The application of shared knowledge to understanding and improving health care and health is the real measure of impact for which we strive.

To read or post commentaries in response to this article, see it online at http://www.annfammed.org/cgi/current/full/5/4/290.

\section{References}

1. Opstelten W, van Loon AM, Schuller $M$, et al. Clinical diagnosis of herpes zoster in family practice. Ann Fam Med. 2007;5(4):305-309.

2. González-González Al, Dawes M, Sánchez-Mateos J, et al. Information needs and information-seeking behavior of primary care physicians. Ann Fam Med. 2007;5(4):345-352.

3. Forrest CB, Shadmi E, Nutting PA, Starfield B. Specialty referral completion among primary care patients: results from the ASPN referral study. Ann Fam Med. 2007;5(4):361-367.

4. Nicholson JM, Yeager DL, Macones G. A preventive approach to obstetric care in a rural hospital: association between higher rates of preventive labor induction and lower rates of cesarean delivery. Ann Fam Med. 2007;5(4):310-319.

5. Dietrich AJ, Tobin JN, Cassells A, et al. Translation of an efficacious cancer-screening intervention to women enrolled in a Medicaid managed care organization. Ann Fam Med. 2007;5(4):320-327.

6. Escobar JI, Gara M, Diaz-Martinez A, et al. Effectiveness of a timelimited cognitive behavior therapy-type intervention in primary care patients with medically unexplained symptoms. Ann Fam Med. 2007;5(4):328-335.

7. Caughey AB. Preventive induction of labor: potential benefits if proved effective. Ann Fam Med. 2007;5(4):292-293.

8. Klein MC. Association not causation: what is the intervention? Ann Fam Med. 2007;5(4):294-297.

9. Noakes K, Yarwood J, Salisbury D. Parental response to the introduction of a vaccine against human papilloma virus. Hum Vaccin. 2006;2(6):243-248.
10. Raley JC, Followwill KA, Zimet GD, Ault KA. Gynecologists' attitudes regarding human papilloma virus vaccination: a survey of Fellows of the American College of Obstetricians and Gynecologists. Infect Dis Obstet Gynecol. 2004;12(3-4):127-133.

11. Stewart AM. Mandating HPV vaccination-private rights, public good. N Engl J Med. 2007;356(19):1998-1999.

12. Sawaya GF, Smith-McCune K. HPV vaccination-more answers, more questions. N Engl J Med. 2007;356(19):1991-1993.

13. Charo RA. Politics, parents, and prophylaxis-mandating HPV vaccination in the United States. N Engl J Med. 2007;356(19):1905-1908.

14. Gostin LO, DeAngelis CD. Mandatory HPV vaccination: public health vs private wealth. JAMA. 2007;297(17):1921-1923.

15. Woodhall SC, Lehtinen M, Verho T, Huhtala H, Hokkanen M, Kosunen E. Anticipated acceptance of HPV vaccination at the baseline of implementation: a survey of parental and adolescent knowledge and attitudes in Finland. J Adolesc Health. 2007;40(5):466-469.

16. Sussman AL, Helitzer D, Sanders M, Urquieta B, Salvador M, Ndiaye K. HPV and cervical cancer prevention counseling with younger adolescents: implications for primary care. Ann Fam Med. 2007;5(4):298-304.

17. Curlin FA, Dugdale LS, Lantos JD, Chin MH. Do religious physicians disproportionately care for the underserved? Ann Fam Med. 2007;5(4):353-360.

18. Ely JW, Osheroff JA, Maviglia SM, Rosenbaum ME. Patient-care questions that physicians are unable to answer. J Am Med Inform Assoc. 2007;14(4):407-414.

19. Ely JW, Osheroff JA, Ebell MH, et al. Obstacles to answering doctors' questions about patient care with evidence: a qualitative study. BMJ. 2000;324(7339):710.

20. Ely JW, Burch RJ, Vinson DC. The information needs of family physicians: case-specific clinical questions. J Fam Pract. 1992;35(3):265-269.

21. Ely JW, Osheroff JA, Gorman PN, et al. A taxonomy of generic clinical questions: classification study. BMJ. 2000;321(7258):429-432.

22. Ely JW, Osheroff JA, Ebell MH, et al. Analysis of questions asked by family doctors regarding patient care. BMJ. 1999;319(7206):358-361.

23. Yu H, Lee M, Kaufman D, et al. Development, implementation, and a cognitive evaluation of a definitional question answering system for physicians. J Biomed Inform. 2007;40(3):236-251.

24. Haggerty J, Burge F, Lévesque J, et al. Operational definitions of attributes of primary health care: consensus among Canadian experts. Ann Fam Med. 2007;5(4):336-344.

25. Stange KC. Annals journal club: challenges in counseling adolescents about HPV vaccine. Ann Fam Med. 2007;5(4):iii.

26. Frey JJ III. Five careers and eight airplanes: an oral history of John Geyman, MD. Ann Fam Med. 2007;5(4):368-370.

27. Garfield E. The history and meaning of the journal impact factor. JAMA. 2006; 295(1):90-93.

28. The Thompson Scientific Impact Factor. http://scientific.thomson. com/free/essays/journalcitationreports/impactfactor/. Accessed June 27, 2007.

29. Journal Citation Reports (Science Edition) [database online]. Philadelphia, PA: Thomson Scientific; 2006. Updated June 11, 2007.

30. Garfield E. How can impact factors be improved? BMJ. 1996;313 (7054):411-413.

31. Walter G, Bloch S, Hunt G, Fisher K. Counting on citations: a flawed way to measure quality. Med J Aust. 2003;178(6):280-281.

32. Seglen PO. Why the impact factor of journals should not be used for evaluating research. BMJ. 1997;314(7079):497.

33. MacRoberts $\mathrm{MH}$, MacRoberts BR. Problems of citation analysis: A critical review. J Am Soc Inf Sci. 1989;40(5):342-349.

34. Saha S, Saint $S$, Christakis DA. Impact factor: a valid measure of journal quality? J Med Libr Assoc. 2003;91(1):42-46. 